\title{
EDUCAÇÃO, CURRÍCULO E TEORIA CRÍTICA EM TEMPOS DE PANDEMIA: O QUE PENSAM DOCENTES E A COMUNIDADE ESCOLAR
}

\author{
EDUCACIÓN, CURRÍCULO Y TEORÍA CRÍTICA EN TIEMPOS DE PANDEMIA: LO \\ QUE PIENSAN LOS MAESTROS Y LA COMUNIDAD ESCOLAR
}
EDUCATION, CURRICULUM AND CRITICAL THEORY IN TIMES OF PANDEMIC: WHAT TEACHERS THINK AND THE SCHOOL COMMUNITY

\author{
Francisco Thiago SILVA ${ }^{1}$ \\ Aurênio Pereira da SILVA ${ }^{2}$
}

RESUMO: Este texto tem como objetivo estabelecer um diálogo crítico, diante do contexto de pandemia que também acometeu a educação, sobre a prática curricular no formato remoto de ensino. Neste contexto, o currículo também parece ter sido contaminado pelo vírus da inacessibilidade e desigualdade social, descaracterizando o estado de direito democrático. Compreendemos que gerenciar a perspectiva crítica neste formato não é fácil, mas é possível. A nossa visão se anuncia como crítica, na medida em que nos posicionamos no grupo das teorias de educação e de currículo do terreno próximas ao pensamento marxiano de explicar o mundo concreto por meio do materialismo histórico dialético. Para tanto, utilizamos como instrumento metodológico a pesquisa bibliográfica para fundamentar as nossas reflexões, e a entrevista semiestruturada com professores, estudantes e mães, no intuito de compreender a educação/ensino no contexto de pandemia, na gama do Ensino Fundamental da Educação Básica. $\mathrm{O}$ artigo traça um panorama sobre o contexto do ensino remoto durante a pandemia e em seguida apresenta, por meio da análise de questionários aplicados aos interlocutores de pesquisa, possíveis saídas para pensar em uma organização curricular crítica mais humana e emancipadora, com vistas ao cenário de retorno aos trabalhos educacionais no cenário pós covid-19.

PALAVRAS-CHAVE: Educação. Ensino remoto. Pandemia.

RESUMEN: Este texto tiene como objetivo establecer un diálogo crítico, en vista del contexto de una pandemia que también afectó a la educación, sobre la práctica curricular en el formato remoto de la enseñanza. En este contexto, el currículo también parece haber sido contaminado por el virus de la inaccesibilidad y la desigualdad social, caracterizando el Estado democrático de derecho. Entendemos que gestionar la perspectiva crítica en este formato no es fácil, pero es posible. Nuestra visión se proclama como crítica, en la medida en que nos posicionamos en el grupo de teorías de la educación y el currículo del terreno cercano al pensamiento marxista de explicar el mundo concreto a través del materialismo

\footnotetext{
${ }^{1}$ Universidade de Brasília (UNB), Brasília - DF - Brasil. Professor Adjunto do Departamento de Métodos e Técnicas. PPGFE-MP. Doutorado em Educação (UNB). ORCID: https://orcid.org/0000-0002-6998-2757. Email: francisco.thiago@unb.br

${ }^{2}$ Secretaria de Educação do Distrito Federal (SEDF), Brasília - DF - Brasil. Professor da Educação Básica. Mestrando no Programa de Pós-Graduação em Educação (UNB). ORCID: https://orcid.org/0000-0003-48981453. E-mail: aurenio2012@gmail.com
}

RIAEE - Revista Ibero-Americana de Estudos em Educação, Araraquara, v. 16, n. esp. 3, p. 1604-1628, jun. 2021. e-ISSN: 1982-5587 
histórico dialéctico. Para ello, utilizamos como instrumento metodológico la investigación bibliográfica para apoyar nuestras reflexiones, y la entrevista semiestructurada con profesores, alumnos y madres, con el fin de entender la educación/enseñanza en el contexto de la pandemia, en el rango de escuela primaria de Educación Básica. El artículo describe una visión general del contexto de la enseñanza a distancia durante la pandemia y luego presenta, a través del análisis de cuestionarios aplicados a interlocutores de investigación, posibles formas de pensar en una organización curricular crítica más humana y emancipadora con miras al escenario de volver al trabajo educativo en el escenario postcovid-19.

PALABRAS CLAVE: Educación. Enseñanza remota. Pandemia.

ABSTRACT: This text aims to establish a critical dialogue, in view of the context of a pandemic that also affected education, about curricular practice in the remote format of teaching. In this context, the curriculum also seems to have been contaminated by the virus of inaccessibility and social inequality, decharacterizing the democratic rule of law. We understand that managing critical perspective in this format is not easy, but it is possible. Our vision is proclaimed as critical, to the extent that we position ourselves in the group of theories of education and curriculum of the ground close to Marxian thought of explaining the concrete world through dialectical historical materialism. For this, we used as a methodological instrument the bibliographic research to support our reflections, and the semi-structured interview with teachers, students and mothers, in order to understand education/teaching in the context of pandemic, in the range of elementary school of Basic Education. The article outlines an overview of the context of remote teaching during the pandemic and then presents, through the analysis of questionnaires applied to research interlocutors, possible ways to think of a critical curricular organization more humane and emancipatory with a view to the scenario of returning to educational work in the post-covid19 scenario.

KEYWORDS: Education. Remote teaching. Pandemic.

\section{Introdução}

Educação e pandemia, adaptar-se é necessário. Tempos difíceis que acarretaram mudanças no ensino e na qualidade da educação básica, isto em virtude do novo coronavírus que se espalhou rapidamente pelo país e pelo mundo. Proliferação letal, se não diagnosticada e tratada com rapidez, caracterizada como pandemia, uma vez que se perde o controle da disseminação e ou surto infectocontagioso.

O ensino remoto, alternativa encontrada para dar prosseguimento ao ano letivo, foi o procedimento adotado pela maioria das instituições seguindo as orientações de suas respectivas secretarias de estado de educação, amparados legalmente pelas instituições superiores e o próprio Estado. Formato que acarreta discussões e debates, principalmente nas questões de acesso, organização curricular e qualidade no ensino. É nesse sentido que 
buscamos refletir a educação em tempos de pandemia: um diálogo sobre a prática curricular numa perspectiva crítica.

Assim, contextualizamos a pandemia da covid-19 e seus desdobramentos no cenário da educação vinculado a uma ótica crítica, pautado na perspectiva de Saviani (2013), de uma prática à luta, emancipação e transformação social, estabelecendo relação com outros autores que imergem na mesma fonte.

No intento de compreender melhor este contexto, adotamos a entrevista semiestruturada como instrumento metodológico, com professores, pais/mães e/ou responsáveis e alguns alunos da educação básica, para assim perceber as suas percepções sobre o formato remoto de ensino. Diante disto, baseados em Silva (2020), ao vislumbrar o retorno presencial da educação, apresentamos algumas adaptações curriculares para a organização do trabalho pedagógico para que esse "novo normal" seja enfrentado com mais serenidade.

\section{Um diálogo necessário: educação em tempos de pandemia}

De início, é válido destacar a luta por uma educação pública, equânime, laica e de qualidade, vislumbrando a disseminação de uma teoria crítica de currículo por meio da interação dialogicizada entre professor-aluno e aluno-professor, é o que nos motiva a permanecer, embora em constante diálogo, nas teorias críticas. Defendemos, assim como Saviani (2013), uma prática curricular crítica, voltada à luta, à emancipação e à transformação social. Nesta constante, almejamos a qualidade desejada ao âmbito da educação, qualidade não restrita à quantificação de resultados, mas que direcione, ou redirecione, os percursos, melhorando os processos e resultados a fim da promoção de uma educação de qualidade social. Relativo a esta vertente, Almeida e Betini (2016, p. 55) nos diz que a perspectiva da qualidade social é a busca pela formação ampla dos sujeitos, a qual deve atingir variados aspectos do ser social na perspectiva de uma formação omnilateral, na intenção de construir uma sociedade menos excludente e desigual. Entendemos também que essa qualidade perpassa por uma série de demandas, seja em recursos humanos, didáticos e econômicos, por isso ratificamos a necessidade de maiores investimentos na área educacional. Este é o momento oportuno de o Estado garantir a acessibilidade e condições de uma educação pública de excelência a todos os estudantes do país. 
No Brasil, com a pandemia da covid-19 instalada no início de 2020, foi possível perceber que, assim como no campo da saúde, a educação, mais especificamente no âmbito ${ }^{3}$ curricular, mostrou-se frágil e precária pela estratégia educativa adotada pela maioria dos sistemas de ensino, qual seja, o ensino remoto. Isto demonstrado por uma pesquisa encomendada ao DataFolha pelo Itaú Social, Fundação Lemann e Imaginable Futures, publicada pelo Correio Brasiliense, jornal local de Brasília DF, onde evidencia em porcentagem a forma de acesso à educação via remota, pelos estudantes do Ensino Fundamental, ambas as etapas, e o Ensino Médio, conforme apresentado a seguir:

Figura 1 - Acessos remotos durante o ano de 2020 por região brasileira

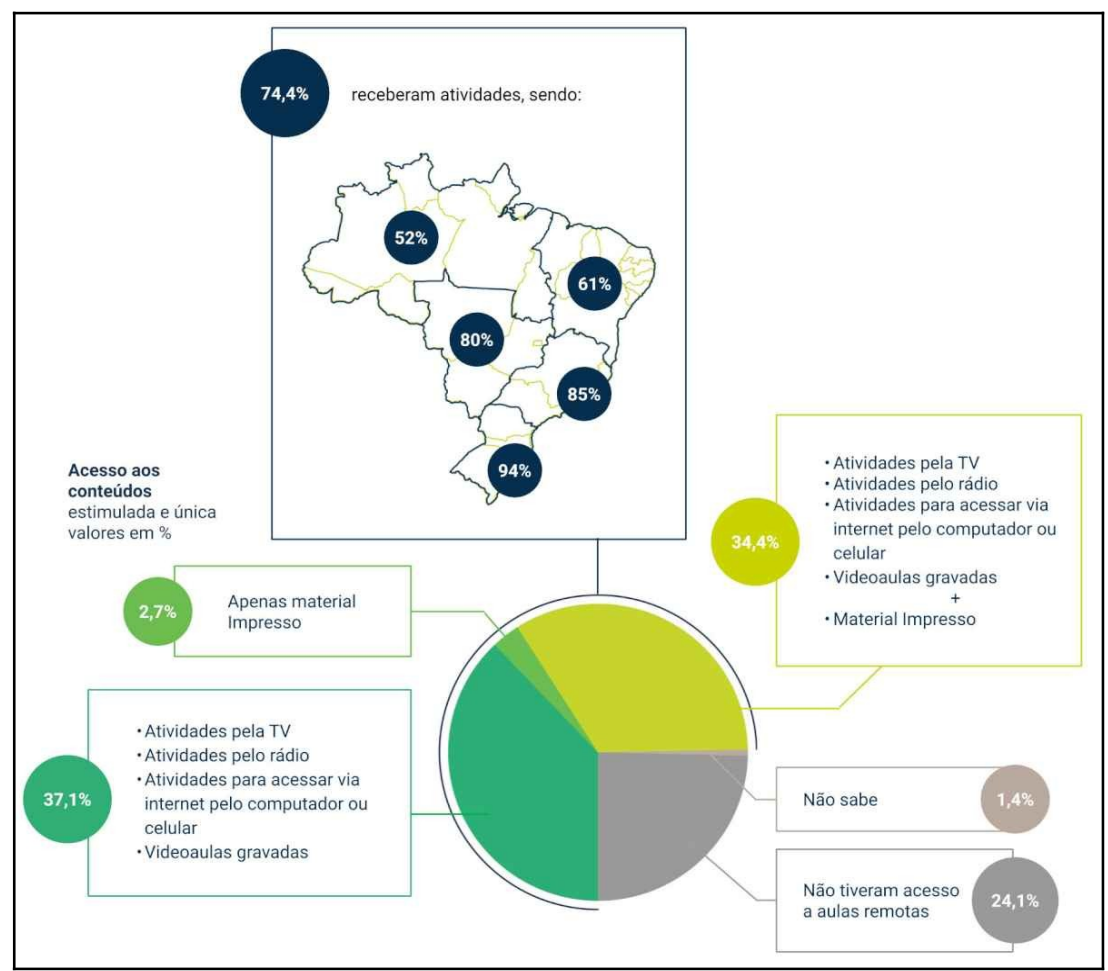

Fonte: Correio Braziliense (s/a) ${ }^{4}$

Esta imagem coaduna com as propostas educacionais dos "parceiros" da educação e ratifica uma outra pesquisa realizada pelo Todos pela Educação ${ }^{5}$, onde apresenta como foi disseminado o ensino pelos estados e municípios brasileiros. Os dados são referentes ao ano de 2020 , e embora seja exaltado que $74,4 \%$ dos estudantes receberam atividades, abrangendo diferentes maneiras, e isso é bom, não devemos esquecer-nos das formas que não houve

\footnotetext{
${ }^{3}$ Em tempo: optamos usar esses dados, gerados por tais instituições, porque até o fechamento desse manuscrito não havia dados oficiais do Ministério da Educação ou de qualquer outro órgão público oficial que nos trouxesse algum cenário numérico a respeito do acesso.

${ }^{4}$ Disponível em: https://www.correiobraziliense.com.br. Acesso em: 22 fev. 2021.

${ }^{5}$ Para maiores informações, visitar o site Todos pela Educação. Nota Técnica: Ensino a distância na educação básica frente à pandemia da covid-19.
} 
interação entre professor e aluno, quando o único meio foi o material impresso, e não podemos desconsiderar ainda o percentual que não sabe e dos que não tiveram acesso às aulas remotas. Estas pesquisas são dados iniciais, datados de abril e junho de 2020, logo os números podem ser ainda maiores, visto a amplitude do território nacional.

Nesse contexto, nos pareceu, como já pontuaram Silva e Borges (2019), que o "currículo é terra de ninguém", é disputa, é conflito. Numa queda de braço ferrenha, em que de um lado estava o Estado e seus apoiadores com a proposta de implementação do ensino remoto. Do outro, alguns sujeitos na sua resistência, a exemplo de pais, docentes e comunidade acadêmica, sendo vencidos por discursos melindrosos e cheios de intenções dos primeiros, que provavelmente emergirão durante e pós-pandemia. Aqui podemos inferir uma possível instituição da homeschooling na educação, dentre outras medidas que poderão ser implementadas a partir dessa experiência com o ensino remoto.

Consideradas essas questões introdutórias, destacamos que a covid-19 é uma doença infecciosa causada pelo novo coronavírus, identificado oficialmente pela primeira vez em dezembro de 2019, em Wuhan, na China. Trata-se de uma doença respiratória cuja transmissão dá-se principalmente de pessoa a pessoa. A dispersão da doença ocorreu rapidamente pelo mundo, levando a Organização Mundial da Saúde, em janeiro de 2020, a declarar que o surto do novo coronavírus constituía uma Emergência de Saúde Pública de Importância Internacional, e a caracterizá-lo, em março, como uma pandemia. ${ }^{6}$

No Brasil, essas declarações levaram os chefes de Estados, nas esferas federal, estadual e municipal, a adotarem medidas preventivas de contenção à propagação do vírus, dentre elas a quarentena ou o isolamento social em diversas áreas, como a educacional. Assim, primeiro os sistemas de ensino paralisaram ou suspenderam as suas atividades presenciais, e em seguida adotaram o ensino remoto, mediado pelas tecnologias digitais, como uma estratégia de continuação das atividades acadêmicas previstas para o ano letivo 2020 .

Apesar das disparidades sociais, regionais e econômicas, as redes de ensino tiveram que buscar formas particulares de minimizar os impactos trazidos pela pandemia e, com a ausência aparente de ações articuladas da gestão federal central, os sistemas de ensino só puderam contar com um eixo normativo legal a partir da atuação do Conselho Nacional de Educação (CNE), por meio do Parecer no 05/2020, que trata da reorganização do calendário escolar e da possibilidade de cômputo de atividades não presenciais para fins de cumprimento da carga horária mínima anual, que em razão de tal pandemia dispôs orientações com vistas à

${ }^{6}$ Foram confirmados no mundo 107.423 .526 casos de COVID-19 e 2.360 .280 mortes até 12 de fevereiro de 2021. Sendo no Brasil, 9.921.981 casos confirmados e 240.940 mortes, fora as subnotificações que sabemos que são inúmeras. Disponível em: https://www.paho.org/pt/covid19. Acesso em: 22 fev. 2021. 
organização do ensino, desde a Educação Infantil ao Ensino Superior. Dentre elas, destacamos as orientações à Educação Básica, por ser o foco da discussão nesse texto:

\section{Quadro 1 - Proposições do MEC ao ensino durante o isolamento social}

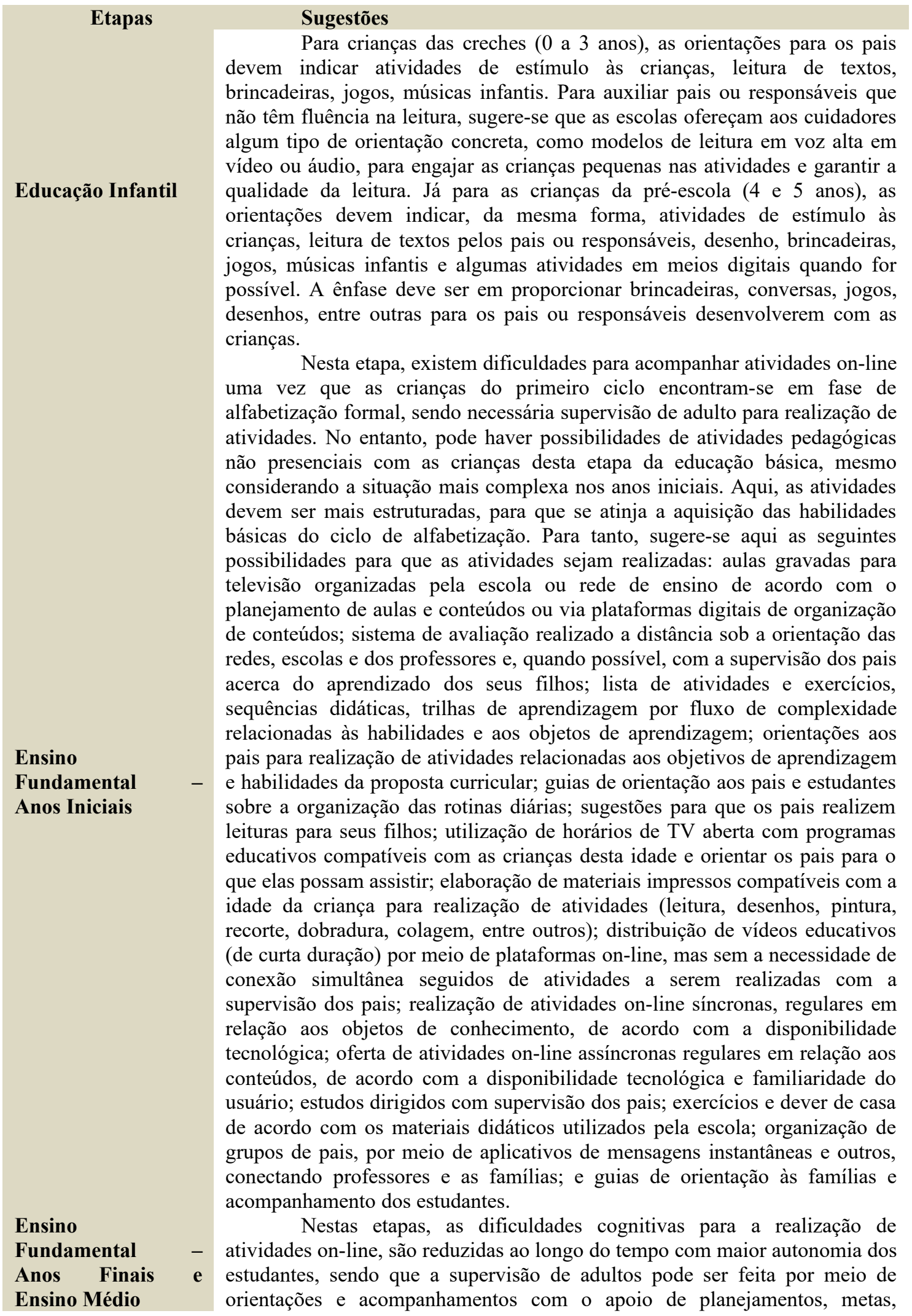


Fonte: BRASIL (2020)

horários de estudo presencial ou virtualmente. Aqui as possibilidades de atividades pedagógicas não presenciais ganham maior espaço. Neste sentido, sugere-se: elaboração de sequências didáticas construídas em consonância com as habilidades e competências preconizadas por cada área de conhecimento na BNCC; utilização, quando possível, de horários de TV aberta com programas educativos para adolescentes e jovens; distribuição de vídeos educativos, de curta duração, por meio de plataformas digitais, mas sem a necessidade de conexão simultânea, seguidos de atividades a serem realizadas com a supervisão dos pais; realização de atividades on-line síncronas de acordo com a disponibilidade tecnológica; oferta de atividades on-line assíncronas de acordo com a disponibilidade tecnológica; estudos dirigidos, pesquisas, projetos, entrevistas, experiências, simulações e outros; realização de testes on-line ou por meio de material impresso, entregues ao final do período de suspensão das aulas; e utilização de mídias sociais de longo alcance (WhatsApp, Facebook, Instagram etc.) para estimular e orientar os estudos, desde que observadas as idades mínimas para o uso de cada uma dessas redes sociais.

De acordo com o CIEB (2020), a partir dessas recomendações, as estratégias adotadas pelas redes estaduais e municipais de educação foram as seguintes: plataformas digitais, redes sociais, materiais digitais, aulas on-line, aulas via TV, orientações e cronograma de atividades para pais e disponibilização de materiais impressos.

Uma pergunta que se faz nesse novo formato escolar é: como se estrutura e se corporifica o currículo numa perspectiva de formação plena e crítica do indivíduo, conforme estabelece a Lei de Diretrizes e Bases da Educação (LDB)? E ainda se pergunta: que modalidade de educação é essa que se desenvolve mediante tamanha desigualdade socioeconômica no Brasil, em que apenas $67 \%$ dos domicílios possuem acesso à internet, sendo que 93\% deles acessam pelo celular (CETIC, 2018)? Podemos falar, então, em uma educação excludente e acrítica?

Neste contexto de crise, foi possível perceber que a pandemia escancarou as desigualdades em diversos setores, principalmente o educacional, o social e o econômico, como podemos observar nos dizeres de Mendes, Lhamas e Maia (2020, p. 362). Vivenciamos uma grave desigualdade econômica que permeia a sociedade brasileira e, no atual cenário, muitos são os setores sociais nos quais essas disparidades históricas se aguçam e se evidenciam. Partir do pressuposto que todos possuem condições de acessar e desenvolver as atividades escolares via remota, seja por computadores ou aparelhos móveis, é uma grande injustiça. Os estudantes não estão no mesmo patamar. Isto é exclusão!

Percebemos que esse regime escolar vai de encontro ao que preconiza a Constituição Federal, em seu Art. 206, no qual dispõe que o ensino será ministrado com base em princípios, dentre eles o de igualdade de condições para acesso e permanência na escola. 
Também contraria a LDB quando estabelece o princípio de educação para todos, com equidade.

É inquestionável que estamos em um momento extremamente atípico, vivido fora da "normalidade" educacional. Escolas, professores e pais estão se reinventando e se "virando nos trinta" para dar continuidade ao processo educativo do aluno. Mas, neste processo de reinvenção, as escolas têm mantido o padrão mínimo de qualidade necessário à aprendizagem, sobretudo à aprendizagem de cunho crítico? O currículo praticado tem possibilitado isso? As "armas" ou os conhecimentos para uma visão crítica da realidade, sobretudo essa realidade em que a pandemia revelou as desigualdades e os problemas socioeconômicos, estão sendo construídas pelos alunos a partir da escola e do adulto em casa? São questões que nos inquietam e certamente inquietam muitos educadores.

Para responder essas questões, consideramos, inicialmente, os pressupostos da Pedagogia Histórico-Crítica, em que à educação:

[...] impõe-se a tarefa de superar tanto o poder ilusório (que caracteriza as teorias não-críticas) como a impotência (decorrente das teorias críticoreprodutivistas), colocando nas mãos dos educadores uma arma de luta capaz de permitir-lhes o exercício de um poder real, ainda que limitado (SAVIANI, 2008, p. 25).

Acreditamos que esse formato escolar e as estratégias adotadas restringem o acesso ao conhecimento, esvaziam o currículo e a formação crítica, na qual os conhecimentos construídos configuram-se enquanto instrumento de luta por uma transformação social. Um ensino remoto de qualidade demanda uma série de recursos tecnológicos eficientes para que o conhecimento, de fato, seja propagado e construído. Para esclarecer o contexto da educação em tempos de pandemia demarcaremos a diferença entre o ensino remoto, ensino híbrido e a EAD (Educação à Distância), visto que observamos alguns equívocos a despeito. O Decreto 9.057/2017, considera em seu Art. $1^{\mathrm{o}}$ que:

[...] educação a distância a modalidade educacional na qual a mediação didático-pedagógica nos processos de ensino e aprendizagem ocorra com a utilização de meios e tecnologias de informação e comunicação, com pessoal qualificado, com políticas de acesso, com acompanhamento e avaliação compatíveis, entre outros, e desenvolva atividades educativas por estudantes e profissionais da educação que estejam em lugares e tempos diversos. (BRASIL, 2017, s/p)

Já o ensino híbrido é uma abordagem pedagógica que combina atividades presenciais e atividades realizadas por meio das tecnologias digitais de informação e comunicação TDICS (BACICH; NETO; TREVISANI, 2017, p. 13). O ensino remoto constitui uma 
alternativa para a manutenção do processo ensino aprendizagem, até pouco tempo realizado na modalidade presencial, onde as aulas ocorrem de modo síncrono (vídeo aulas, aula expositiva por webconferência etc) e assíncrono, por meio de atividades em ambiente virtual de aprendizagem - AVA. Sabemos que na escola pública muitas famílias não têm esse acesso. Demanda, ainda, um sistemático acompanhamento e suporte dos pais ou familiares nas atividades dos alunos. Sabemos que isso não ocorre em razão da escolaridade e de muitos formatos de famílias que temos no Brasil.

Gerenciar o trabalho pedagógico em tempos de aulas remotas é um desafio hercúleo, pois demanda uma verdadeira re-organização do trabalho pedagógico, desde a elaboração e estrutura curricular, passando pela didática, estratégias metodológicas e formas avaliativas. Mas, mais que em qualquer outra época, precisamos compreender a importância de distinguir a educação familiar e a educação escolar. Libâneo (2013) nos apresenta que a atividade educativa acontece nas mais variadas esferas da vida social, inclusive no ambiente familiar. Porém, a educação escolar é sistematizada, tem caráter pedagógico e democrático, visando ao desenvolvimento pleno do indivíduo. Nela, o aluno tem acesso aos mais variados conhecimentos construídos historicamente e legitimados socialmente. Assim sendo,

[...] o caráter pedagógico da prática educativa se verifica como ação consciente, intencional e planejada no processo de formação humana, através de objetivos e meios estabelecidos por critérios socialmente determinados e que indicam o tipo de homem a formar. [...] O processo de ensinoaprendizagem é, fundamentalmente, um trabalho pedagógico (LIBÂNEO, 2013, p. 24).

É preciso lembrar que vivemos uma nova anormalidade no mundo contemporâneo e não devemos alvitrar que neste momento o trabalho pedagógico passe a ser responsabilidade dos familiares responsáveis de nossos alunos. Sabe-se que a educação também é dever da família e que é inquestionável a sua importância e participação nesse processo educativo dos estudantes. No entanto, é dever da escola desempenhar a sua função, sobretudo no bojo da perspectiva social - a formação para a cidadania pela ótica crítica - e delegar aos pais o acompanhamento e a orientação nesse processo. Conforme preconiza Saviani (1996, p. 3),

[...] considerando-se que toda relação de hegemonia é necessariamente uma relação pedagógica, cabe entender a educação como um instrumento de luta. Luta para estabelecer uma nova relação hegemônica que permita constituir um novo bloco histórico sob a direção da classe fundamental dominada da sociedade capitalista - o proletariado. 
Considerando a contraditória história de formação e realidade do nosso país, o autor salienta a necessidade de formar o cidadão numa perspectiva política, sob o olhar do dominado e não do dominante. Para tanto, ele aponta como função social da escola a formação crítica do aluno a partir do acesso e domínio do conhecimento escolar, que partem da prática social desse sujeito. Para Saviani (1996), existem três elementos que são preponderantes nesse processo: a elevação do nível cultural das massas, a crítica à concepção dominante e a validação do senso comum, que é a elevação da consciência filosófica da pessoa. Em outras palavras, isso quer dizer que o papel da escola é propiciar o avanço cognitivo do aluno, partindo da sua prática social cotidiana, problematizando-a e instrumentalizando-o de forma que o conhecimento construído seja instrumento para a transformação social.

Esse processo metódico e intencional não ocorre pela educação da família, mas de forma institucional, como aponta Cunha (2006, p. 444), que descreve a ação educativa como sendo o " $[\ldots]$ exercício intencional que emprega energias humanas capazes de produzir um efeito pedagógico, passando do projeto à sua realização". E esta intencionalidade reverbera no próprio currículo, quando se faz o planejamento e sua aplicação, assim como no avaliar.

Pensemos, então, na questão curricular nesse contexto em que a educação passou a acontecer de acordo com as condições que as escolas e os estudantes possuem. Se no regime presencial a perspectiva crítica de ensino pouco se efetiva, imaginamos agora, via ensino remoto. Já temos um currículo mínimo "garantido" pelas legislações vigentes, e esse mínimo neste tempo pandêmico pode se tornar ainda mais minimizado ou esvaziado por meio de atividades selecionadas, reduzidas e descontextualizadas. Será que as instituições têm prezado pela qualidade do ensino e pela seleção de conteúdos valiosos à formação crítica dos estudantes? Ou será que têm se pautado no conteudismo disponibilizado nas plataformas digitais ou redes sociais, sem levar em conta o currículo prescrito (SACRISTÁN, 2000) e suas vertentes?

Apresentada essas indagações, não estamos generalizando o ensino remoto como algo que não deu certo, ao contrário, entendemos que esta foi a forma encontrada para amenizar os impactos de um ano letivo, e sabemos também que houve e há validez nesta nova modalidade de ensino. Para tanto, as nossas reflexões são para que, no retorno, possamos retomar uma postura de construir novos saberes com base em epistemologias históricas e críticas, saindo da prescrição e colocando-a em prática, até mesmo por meio dos aparatos utilizados no ensino remoto. 
Considerando isso, cabe falarmos sobre a importância do currículo em ação, aquele que se efetiva na prática, partindo da prescrição, visto que este é o que prevalece, implicando valores e intenções à prática educativa. Para tal, Sacristán (2000, p. 201) destaca que:

[...] o valor de qualquer currículo, de toda proposta de mudança para a prática educativa, se comprova na realidade na qual se realiza, na forma como se concretiza em situações reais. O currículo na ação é a última expressão de seu valor, pois, enfim, é na prática que todo projeto, toda ideia, toda intenção, se faz realidade de uma forma ou outra; se manifesta, adquire significado e valor, independentemente de declarações e propósitos de partida. Às vezes, também, à margem das intenções, a prática reflete pressupostos e valores muito diversos.

Por este caminho, entendemos que a prática pedagógica é "[...] uma rede viva de troca, criação e transformação de significados" (GÓMEZ,1998, p. 85), buscando sempre a autonomia e caráter emancipatório do sujeito. Logo, o papel e a presença do professor são extremamente essenciais. Nesse contexto em que os estudantes estudam em casa, a escola não pode delegar essa responsabilidade aos familiares. Não estamos, de forma alguma, menosprezando o desempenho dos familiares ou responsáveis ou retirando deles a função de educar. Apenas estamos destacando que o trabalho sistemático, com base em pressupostos pedagógicos e curriculares, é de responsabilidade da escola, de modo geral, e do professor, de modo específico. É a prática desse profissional que leva ou não o aluno a desenvolver as competências e habilidades previstas no currículo.

No contexto atual denotamos algumas preocupações, dentre elas a minimização dos conteúdos, que correlacionamos com o estreitamento curricular de que trata Freitas (2018), no qual enfatiza determinados conteúdos disciplinares e secundariza outros. Para o autor, o sentido desse estreitamento se relaciona às políticas que,

[...] reduzem o conceito de educação ao de aprendizagem de Leitura e Matemática em testes padronizados, usualmente de múltipla escolha, e induzem a escola a se concentrar nessas disciplinas, elas esvaziam a ênfase da escola em outras disciplinas como as Artes, História, Filosofia etc. (FREITAS, 2018, p. 139).

$\mathrm{O}$ fato de considerarmos que no ensino remoto pode ocorrer o "estreitamento educacional e curricular" - também sinônimo de reducionismo ou esvaziamento da educação e do currículo - se reporta à questão de que na atual reorganização escolar e, diante das limitações das tecnologias digitais e do ensino por meio de materiais impressos aos estudantes, coloca-se em xeque o acesso aos conceitos e às fundamentações teóricas e críticas, os quais tanto debatemos e, na medida do possível, colocamos em prática. 
Freitas (2018) ainda adverte que o efeito desse processo de esvaziamento/estreitamento traz um efeito perverso que se escancara no fator desigualdade de acesso aos diversos instrumentos de conhecimento e de perspectivas futuras. Não nos restam dúvidas que ocorre nesse processo uma educação dualista ou diferenciada entre os mais variados grupos sociais: uma formação intelectual ou acadêmica aos ricos, e uma educação rasa, mínima, aos pobres.

Além disso, o que pode ocorrer são as perdas intelectuais, já que a grande maioria dos estudantes brasileiros, via ensino remoto precário, terão um esvaziamento no processo formativo em decorrência da prática curricular posta em ação; não estamos afirmando, contudo, que o ensino remoto é um fracasso total ou que não deveríamos ter ficado de "braços cruzados", em absoluto! Ocorre que a pandemia nos acendeu mais um alerta importante a respeito da urgência em proteger a escola pública e a necessidade de levantar os debates acerca das políticas públicas de acesso às tecnologias da informação e da comunicação imbricadas nos mais modernos processos de ensino e de aprendizagem, de modo a evitar que o fosso da desigualdade social que assola nosso país se vulcanize no currículo, e consolide o dualismo, o que apropriadamente Libâneo (2012) classificou como perversidade em nossa sociedade educativa: uma escola do conhecimento para os ricos e outra do acolhimento social para os pobres.

Em meio à pandemia nos vemos em situações distintas de distanciamento, não somente social, mas também de conhecimento ou intelectual. Talvez o conhecimento construído nesse contexto em que os estudantes se encontram em casa careça de uma perspectiva cientifica e crítica. Muitos deles são construídos por meio de recursos midiáticos carregados de preceitos ideológicos desorganizados ou por pessoas que desconhecem as formas de desencadeamento da aprendizagem, a exemplo da importância e necessidade da didatização. Para Bezerra (2008, p. 135), didatização é,

[...] o processo de transformar um determinado assunto de uma área de conhecimento em objeto de ensino, a ser apresentado em sala de aula. [...]. Assim, a didatização remete às reformulações por que passa um conhecimento, a fim de que se possa introduzir o aprendiz no campo desse conhecimento.

Nessa dimensão didático-pedagógica, percebe-se que os professores têm se reinventado para fazer o que de melhor possam oferecer, adaptando-se como podem e com os recursos escassos disponíveis. E nesse processo de reinvenção, Libâneo (2010, p. 140), fundamentando-se em Vasquez (1977), afirma que é necessário pensar na (re)organização do 
trabalho pedagógico enquanto, “[...] educação das consciências, de organização dos meios materiais e planos concretos de ação; tudo isso como passagem indispensável para resolver ações reais, efetivas". Neste sentido, não se pode perder de vista a tríade da organização do trabalho pedagógico, conforme preconizam Lima e Silva (2020, p. 18-19):

Trata-se de alinhar o currículo (a forma como o conhecimento está estruturado) à didática (de que maneira a escola irá se organizar metodologicamente na consolidação de suas ações) e à avaliação (processo imprescindível onde se pode perceber de que maneira a própria OTP está sendo posta em prática).

Para além do perigo viral, corremos um sério risco de que, frente a tais limitações didático-pedagógicas, as desigualdades ampliem ou aprofundem-se nesse contexto, pois a aprendizagem pode não se efetivar, ou pode efetivar-se para uns, e outros não. Além disso, é válido destacar que o contexto é bastante oportuno para que entusiastas do homeschooling (educação escolar em casa) se aproveitem da situação para fazer suas interferências "pedagógicas", caracterizadas em suas ambições econômicas para propagar pacotes educacionais e diminuir a valorização das instituições escolares, possivelmente alegando que a qualidade do sistema educativo esteja no âmbito familiar, usando da ideologia tecnológica e do consumo para precarizar a educação nas escolas. Neste sentido, Silva (2020, p. 3) argumenta que:

[...] tentar forçar uma situação "quase normal" ainda que sob o discurso de complementação de estudos em casa, pode gerar argumentos perfeitamente cabíveis para um novo desenho educacional muito mais desigual do que esse que temos: a obsolescência do papel docente e da escola enquanto instituição material e física para emancipação humana.

Outra questão ou perigo percebido nesse contexto de pandemia é a implementação ou mesmo a sugestão impositiva da EaD (Educação a Distância) sobre o ensino presencial. Será que a educação remota pode ser considerada uma introdução para a implantação da $\mathrm{EaD}$ na Educação Básica? Enfim, são algumas questões que trazemos como preocupação e reflexão, já que esse nível de ensino demanda uma organização sistematizada e processos didáticopedagógicos bem direcionados e bem desenvolvidos para que a aprendizagem e o desenvolvimento pleno do estudante aconteçam. Neste sentido, Saviani (2020) reforça que a EAD já tem existência regulamentada, coexistindo com a educação presencial como uma modalidade distinta, oferecida regularmente. E ainda, ao encontro dos nossos pensamentos e reflexões, o autor ratifica que o ensino remoto é posto como um substituto do ensino 
presencial, excepcionalmente neste período da pandemia, em que a educação presencial se encontra interditada.

\section{O que pensam nossos interlocutores de pesquisa}

Com o objetivo de compreender melhor a educação no contexto de pandemia da covid-19 e de ratificar ou refutar os pressupostos elencados acima, realizamos uma pesquisa com alguns sujeitos que vivenciaram esse fenômeno, quais sejam: seis professores da Educação Básica, dentre eles cinco da rede pública e um da rede privada; seis alunos, sendo um do Ensino Superior da rede privada e os demais do Ensino Fundamental - Anos Finais da rede pública, cuja faixa etária está entre 12 e 16 anos de idade; e cinco mães. A definição desses sujeitos justifica-se pela diversidade em termos de experiências, papéis e níveis socioeconômico e cultural entre eles.

O nosso objetivo ao realizar a entrevista semiestruturada com os partícipes da pesquisa foi conhecer as suas percepções acerca desse novo formato escolar, implementado no país em uma conjuntura excepcional. Sabemos que existem outros olhares e concepções acerca do assunto, por isso o que apresentamos é apenas um recorte de um universo diverso. O que apresentamos expressa o significado do fenômeno ou a realidade vivenciada por esses sujeitos residentes no Distrito Federal e entorno ${ }^{7}$. Cumpre enfatizar que dentro dessas percepções interessa-nos a dimensão curricular do ensino desenvolvido.

As entrevistas foram realizadas no período em que estavam ocorrendo as aulas remotas, especificamente no mês de agosto de 2020, por meio de telefone celular/WhatsApp, considerando o momento de isolamento social. Ao grupo de alunos foram feitos os seguintes questionamentos: a) Qual a sua concepção acerca das aulas e/ou atividades remotas? b) Como é o trabalho desenvolvido pela escola? c) Há problematização do conteúdo trabalhado pelo professor? d) Ele relaciona o conteúdo aos problemas da realidade em que a escola se situa? Ao grupo de professores, questionamos: a) Qual a sua concepção/percepção acerca do ensino remoto desenvolvido na escola onde você trabalha? b) Esse formato possibilita desenvolver práticas conforme preconiza o currículo adotado em termos de aprendizagem e princípios formativos? c) Para você, a formação crítica se efetiva nesse formato escolar? E às mães,

\footnotetext{
${ }^{7}$ Entorno são 34 municípios goianos e mineiros que compõem a RIDE (Região Integrada de Desenvolvimento do Distrito Federal e Entorno), instituída pela Lei Complementar no 94/1998. São municípios que mantém relações metropolitanas com o DF.
} 
perguntamos: a) Qual a sua visão acerca do ensino que o seu filho está tendo durante esse isolamento social?

Segundo os relatos dos alunos há exageros de atividades, falta de preparo de alguns professores para lidar com as plataformas digitais ou os aplicativos adotados pela escola e falta de orientação quanto ao desenvolvimento de determinadas atividades disponibilizadas. Isto evidenciado na fala do aluno 4: “[...] as vezes o professor manda a gente fazer um monte de páginas do livro, tirar foto e enviar, algumas tarefas nem dou conta de fazer. As vezes a gente é expulso da sala e professor não coloca a gente de volta". Isso leva-nos a refletir sobre as especificações de um currículo com vistas à formação crítica e emancipatória, que pode não acontecer, pois como vislumbra Saviani (2008, p. 53-54), a Escola Nova atingiu o método tradicional não em si mesmo, mas em sua aplicação mecânica cristalizada na rotina burocrática do funcionamento das escolas. Neste sentido, deduzimos que a escola, em alguns momentos, tem falhado em cumprir a sua função, sobretudo a função de desenvolver integralmente o estudante em suas múltiplas dimensões, incluindo a formação para a cidadania.

Além disso, quatro dos estudantes, que podem perfeitamente representar a maioria dos estudantes das escolas públicas do país, relataram que o ensino via remoto é muito cansativo e apresenta alguns problemas, tais como o acesso, pois nem sempre a conexão favorece a acessibilidade; local não apropriado para os estudos, já que no ambiente doméstico há barulhos e movimentos que lhes tiram a concentração. Todavia, eles dizem que estão se adaptando a esse regime e desenvolvendo uma rotina de estudos do modo que podem. Cumpre destacar que essa queixa em relação ao acesso partiu dos alunos da rede pública de ensino. Percebemos realidades muito diversas entre o grupo de alunos. Isso já era previsto, como detalhamos na metodologia acima. Enquanto aqueles dizem que o acesso e as condições de estudo não são favoráveis, para o estudante da rede privada tais questões não são vividas, em razão das condições favoráveis que possui.

Essas primeiras informações podem ser evidenciadas nas seguintes falas: a) "[...] as aulas são cansativas e de difícil assimilação dos conteúdos. O acesso às aulas é tranquilo, mas tenho mais facilidade quando o professor explica em presencial do que por vídeo" (ALUNO 1); b) "Em minha visão as aulas remotas são essenciais. Sou muito privilegiado, tenho um canto tranquilo e sem interrupções, internet e possibilidades de imprimir” (ALUNO 2); c) "Estou achando o ensino remoto um pouco difícil, mas estou fazendo aos poucos. Eu saio de casa vou pra casa da minha avó pegar net, porque em casa a net não é boa, mais agora tá dando pra fazer tudo em uma boa" (ALUNO 3). 
Pelos relatos dos alunos, percebemos que o ensino desenvolvido pode estar deixando a desejar, e que a questão curricular está centrada no conteúdo ou nas atividades de forma acrítica. Todos os estudantes relataram a ausência de criticidade e observância da realidade vivida nas aulas dos professores. Ao associarmos essa denúncia aos pressupostos da Pedagogia Histórico-Crítica, é possível pensar o quanto a prática social inicial e a problematização podem estar negligenciadas, o que pode levar a problemas no processo de instrumentalização, catarse e no desenvolvimento de práticas sociais mais conscientes e transformadoras.

Considerando essa pedagogia, Saviani (2013) assevera que "[...] o saber é objeto específico do trabalho escolar" e instrumento para a luta social. Por isso, deve ser construído partindo da prática social dos estudantes e voltando-se a ela. Dois dos estudantes declararam que: “O conteúdo não é explicado, nem problematizado, como você perguntou. Geralmente fazemos leitura dele e respondemos as atividades" (ALUNO 6); "Os conteúdos têm sido explicados de acordo o nosso livro. Geralmente, como é na plataforma não há conversa. Não falamos da nossa realidade nem ele fala dos problemas que existem onde a gente mora" (ALUNO 4).

Nos relatos dos professores foi possível notar descontentamento com o ensino remoto, embora reconheçam que, no contexto de pandemia, esse regime tornou-se necessário à continuidade das atividades acadêmicas. Em suma, os relatos dos professores se situam nos quesitos qualidade, controle, desigualdade, desafio, acesso. Um dos professores diz que:

Na minha visão é muito desafiador, chega a ser triste em algumas situações. Sou professora do ensino médio noturno e os alunos estão desinteressados. Mas, quando falo em tristeza me refiro à falta de condições econômicas para acessar as atividades. Vou confessar que as vezes chorei com algumas situações vividas por eles. Mas, no momento em que estamos vivendo é uma saída para não parar tudo. Então acho válido, no entanto acredito que se disponibilizassem internet gratuita faria muita diferença (PROFESSOR 3).

Outros professores afirmaram que: "[...] as dificuldades para lidar com o ensino remoto foram muitas, pois muitos professores não sabiam nem transformar um documento do Word para o PDF e isso dificultou o trabalho de muitos de nós" (PROFESSOR 5). "Esse ensino remoto não substitui o ensino presencial, não tem como alcançar uma aprendizagem de qualidade, não tem como saber se os alunos estão fazendo as atividades e se estão entendendo os conteúdos, pois as atividades não são on-line" (PROFESSOR 2).

Para um dos professores, a preocupação curricular centra no trabalho voltado às avaliações em larga escala que estão por vir, pois diz que têm trabalhado com foco nos 
conteúdos e nas disciplinas que caem nessas provas. Ele diz que: "O currículo continua sendo seguido, com pequenas alterações nos instrumentos de avaliação. Vivo em uma realidade de duas escolas privadas no DF, onde as avaliações são realizadas via sistema remoto, com questões objetivas no formato ENEM (A-B-C-D-E)" (PROFESSOR 3). Já para outro professor, "[...] ]o formato de ensino remoto não está conseguindo seguir o currículo de forma adequada, pois não conseguimos trabalhar da maneira que devia. Vejo que muitos colegas estão trabalhando com nível de dificuldade baixo. As explicações estão sendo feitas de forma reduzidas, diferente do regime presencial" (PROFESSOR 6).

Quanto ao trabalho desenvolvido numa perspectiva crítica, as entrevistas realizadas evidenciaram que o ensino remoto limita o trabalho pedagógico do professor. Há, ainda, a realidade de duas escolas que estão entregando materiais impressos para os estudantes que não têm acesso à internet. Essas duas realidades, segundo os professores, com exceção do professor da escola privada, configuram-se enquanto empecilhos para o diálogo com os estudantes e uma aproximação maior, dificultando a problematização e a consideração das suas realidades e experiências.

Os pais, assim como os professores e alunos, relataram preocupação com o processo de ensino-aprendizagem mediado pelas tecnologias digitais, como pode ser verificado nessas falas:

\footnotetext{
"Fico preocupada com as disciplinas de exatas, pois é muito dificil a compreensão sem um professor presencial. E eu não consigo ajudar a minha filha nessas disciplinas. Nas outras disciplinas está tranquilo, minha filha consegue fazer sem minha ajuda" (MÃE 1); "As atividades on-line requerem da gente acompanhamento, pois o meu filho não consegue fazer sozinho. Primeiro porque ele não entende alguns conteúdos, segundo porque há um acúmulo de atividades. Mesmo assistindo vídeos produzidos pelos professores, bate uma incerteza do certo ou errado na execução das tarefas" (MÃE 2); "Embora eu reconheça que as escolas estão fazendo o melhor que podem e que o ensino remoto é o recurso para que as aulas continuem, considero-o ineficiente. Fico muito preocupada com a aprendizagem do meu filho nesse ano" (MÃE 3); "Como mãe de criança na alfabetização eu estou sentido que ela será prejudicada duramente porque a escola está passando as atividades, estamos seguindo a apostila, mas assim eu e a avó, estamos tentando alfabetizar na questão da leitura, mas não é a mesma coisa que na escola. Então ela será prejudicada futuramente" (MÃE 4). Outra mãe afirma que: "Tenho acompanhado o meu filho nas aulas online de segunda a sexta-feira, mas a gente faz o que dá, pois tenho que ir à casa da minha irmã para ter acesso à internet. Além disso, tem coisas que eu não sei, outras vezes a escola manda muita tarefa sem explicação dos conteúdos ou fica repetindo conteúdos de séries anteriores" (MÃE 5).
} 
Analisando os relatos das mães, percebemos que o ensino remoto tem dificultado a aprendizagem dos estudantes mesmo tendo também possibilitado em partes. Ora porque tem sido conteudista ou reducionista desses conteúdos, ora porque o professor não tem conseguido desenvolver o seu papel enquanto mediador do processo de ensino-aprendizagem e as mães não conseguem auxiliar/ensinar os seus filhos, em casa. Além disso, foi possível perceber que o fator acesso à internet e as estratégias disponibilizadas nelas, como os vídeos ou materiais digitais por si mesmos, também se constituem em empecilhos ao desenvolvimento dos alunos.

De acordo com as orientações do MEC via Parecer $n^{\circ} 5 / 2020$, cabe às escolas orientarem as famílias para acompanharem a resolução de atividades pelos estudantes. Todavia, ele destaca que essas se constituem mediadores no processo de desenvolvimentos das atividades escolares em casa e que os seus trabalhos não substituem a atividade profissional do professor. O que fazer nesse caso em que, segundo o olhar das mães e alunos, a escola não tem conseguido desenvolver a função primordial? Os responsáveis pelos estudantes, sejam pais, mães, avós e outros, talvez não compreendam de fato a principal função da escola, visto que para muitos deles, a função é meramente ensinar e/ou transmitir o conteúdo, porém a função do professor enquanto instituição está para além disso, como podemos observar nas proposições de Saviani (2013) quando diz que a função da escola seja a socialização do saber sistematizado. E contribui ainda mais ao orientar que o ponto de partida do ensino não é a preparação dos alunos, cuja iniciativa é do professor (pedagogia tradicional), nem a atividade, que é iniciativa dos alunos (pedagogia nova). O ponto de partida seria a prática social, que é comum a professor e alunos (SAVIANI, 2008, p. 56). As constatações dessas mães ratificam, em partes, as nossas suposições iniciais ao afirmarmos que o ensino remoto pressupõe exclusão, perda da qualidade e aprofundamento das desigualdades.

Quanto às práticas curriculares, notamos que o foco dos professores não tem sido a formação crítica do aluno, mas o alcance da aprendizagem mínima ou da aprendizagem necessária ao bom desempenho em avaliações padronizadas. Nesse sentido, Santomé (2016) corrobora que uma educação neoliberal estará orientada para preparar seres consumidores, críticos com os seus interesses enquanto consumidores, mas não para serem capazes de imaginar e refletir sobre que modelos de sociedade são mais justos e respeitadores dos interesses coletivos. Nesta mesma vertente, Sacristán (2000, p. 44) compreende que a preocupação pelos temas estritamente curriculares surge em parte por conveniências administrativas, antes que por uma necessidade intelectual. E ainda complementa que esta situação tem acompanhado toda uma tradição de pensamento e pesquisa psicológica e 
pedagógica acultural e acrítica (SACRISTÁN, 2000, p. 47). Concomitante aos autores, percebemos que o currículo, nestas condições, deixa de cumprir sua função enquanto objeto social e da prática em torno de si mesmo, para servir os interesses do capital.

Sobre esse treinamento para tais avaliações, consideramos que a escola desenvolve uma pedagogia dos resultados, por isso, mesmo on-line, é preciso manter o ranqueamento das "melhores cabeças" (SAVIANI, 2007). Além dessa questão, é válido ressaltar que, para alguns docentes, os da rede pública, o ensino remoto, sobretudo pelo acesso ou recurso digital utilizado, dificulta o desenvolvimento de metodologias de pedagogias críticas: o diálogo com o estudante e a escuta dos seus conhecimentos, a problematização desses, dentre outras questões que envolvem o desenvolvimento da consciência desses sujeitos, que é fundamental à intervenção e transformação social.

Ao analisar esses relatos, foi possível perceber que contextos antagônicos permeiam a realidade desses sujeitos e a organização educacional, de modo geral. As desigualdades nos levam a questionar: Que política de educação é essa que segrega os estudantes e contribui para o aprofundamento das disparidades entre eles? Nesse contexto dual, Saviani (2008, p. 39) assevera que: “[...] o abandono da busca da igualdade é justificado em nome da democracia, e é nesse sentido também que se introduzem no interior da escola procedimentos ditos democráticos". Sabemos que a questão da equidade na educação é um problema histórico, pois desde a sua origem a educação foi marcada pela dualidade à luz da dimensão socioeconômica.

\section{Por um "currículo de transição" (SILVA, 2020)}

Com as contradições já instaladas, pensamos no período pós-pandemia, no trabalho dos sistemas de ensino e das escolas, na reorganização pedagógica e curricular para cada série/ano/modalidade. Não sobram dúvidas que o trabalho será árduo e deve ser humanamente repensado, com vistas a suprir essas deficiências ou problemas provocados pelo ensino desenvolvido no contexto da pandemia. As instituições devem se organizar de modo que não prejudiquem, ainda mais, o alunado e os profissionais da educação, sobretudo os professores, com sobrecarga da jornada, de conteúdos e atividades escolares. O momento será de organização e desenvolvimento de um trabalho voltado ao desenvolvimento do indivíduo em suas múltiplas dimensões, considerando o nível e condições cognitivas e psicológicas de cada um, com foco na superação das desigualdades desencadeadas e a construção do conhecimento científico. 
Nessa perspectiva, Silva (2020, p. 5-6) sugere que, para o retorno das atividades presenciais, sejam feitas algumas adaptações no currículo e no trabalho pedagógico, de modo geral. Segundo ele, é possível pensar num "currículo de transição" com as seguintes características:

a) Precisaremos de um esforço coletivo e solidário para adaptar a Organização do Trabalho Pedagógico (currículo, didática e avaliação); não se trata de desenvolver um "currículo mínimo", aquele no qual apenas alguns conteúdos são pinçados e considerados relevantes, normalmente sem uma ampla discussão; também não se trata apenas de uma adaptação/adequação do que não poderá ser trabalhado, ou seja, o currículo precisa superar a visão meramente como uma grade conteudista;

b) Devemos repensar horários e carga horária, além das metodologias de trabalho que sejam mais dinâmicas, flexíveis e seguras;

c) É preciso implantar formas de avaliação mais humanas e eficientes ao mesmo tempo;

d) Torna-se necessário priorizar uma proposta pedagógica que não cause mais sofrimento do que houve esse ano, na qual a colaboração de todos os sujeitos implicados com a prática pedagógica é de extrema importância. Isso inclui, sobretudo, as famílias dos estudantes;

e) Uma boa saída é o chamado "trabalho por projetos", por temas, por eixos integradores/estruturantes e transversais;

f) É preciso investir em mídias e tecnologias (desde que o acesso seja de $100 \%$ dos usuários) para que a escola permaneça como um espaço democrático de acesso ao conhecimento;

g) É fundamental enxugar matérias, temas, excesso de tarefas e otimizar tempo, espaço, conteúdo e forma.

Ao sugerir as adaptações curriculares, denominado pelo autor, como já pontuamos no chamado "currículo de transição", as diferimos das adaptações curriculares que envolvem o ensino especial, assim como a homogeneização do currículo: trata-se de pensar o ensino remoto, a forma como foi ofertado e/ou disponibilizado, o acesso à aprendizagem dos estudantes, as dificuldades enfrentadas por todos os envolvidos, e pensar também nas possibilidades de aprendizagem, fazendo uso das tecnologias, não como único meio, mas como mais um instrumento de ensino-aprendizagem. É necessário refletir esses pontos, dentre 
outros, e repensar a organização do trabalho pedagógico, permeado pela didática, currículo e avaliação, pois estamos regressando de um percurso em que os obstáculos de uns não foram os de outros. O pensar coletivo nessa retomada presencial e curricular é imprescindível para tentarmos reparar alguns danos causados pelo ensino remoto, assim como pelo devastador vírus causador da Covid-19.

Neste sentido, assim como Silva (2020), defendemos um projeto de retorno às aulas presenciais voltado à superação das desigualdades que o atual projeto excludente de educação provocou. Todavia, a pesquisa revelou que a educação desenvolvida em tempos de pandemia é segregadora, ineficiente, de baixa qualidade, acrítica, e contribui fortemente ao aprofundamento das diferenças educacionais e sociais no país. Reiteramos que à escola cabe disseminar o saber sistematizado, metódico e científico, desenvolver o pensamento crítico do indivíduo e possibilitar o seu desenvolvimento integral.

\section{Considerações finais}

A pandemia deixará cicatrizes ao longo do caminho, cicatrizes por vezes dolorosas, mas também de vitórias. No caso da educação, poderemos colher alguns frutos amargos advindos do aproveitamento neoliberal deste contexto: a defesa do homeschooling, por alguns entusiastas e "empreendedores" da educação, o esvaziamento e o fortalecimento do estreitamento curricular (FREITAS, 2018), assim como a demonstração de controle e poder do fazer pedagógico.

As percepções apresentadas pelos interlocutores da pesquisa mostraram-nos alguns aspectos que corroboram com as nossas perspectivas, sejam elas: a consciência de que o ensino não é o ideal, mas é o que temos para o momento; a comprovação do estreitamento curricular em que as atividades estão centradas nas disciplinas avaliadas nos exames externos. A preocupação com o aprendizado e a desigualdade social e de acesso também é desvelada, assim como a limitação encontrada pelos professores para disseminar um ensino mais crítico e transformador.

Dentro das nossas reflexões, compreendemos todos os empecilhos e/ou dificuldades encontradas no ensino remoto, porém não é por termos esta compreensão que o olhar crítico frente a estes propósitos ficará ausente. Ao contrário, é preciso refletir todas estas questões para em um futuro breve amenizar esses efeitos colaterais causados pelo processo pandêmico ao sistema educacional. Neste sentido de amenização reiteramos que o retorno presencial necessita ser pensado de forma a superar as desigualdades provocadas por este formato 
excludente de ensino, que na sua essência caracterizou-se em um ensino para poucos, embora tenhamos percebidos esforços contínuos da classe trabalhadora para manterem os seus inseridos neste processo. Mas é sabido que muitos se perderam e ainda podem vir a se perder,

isto é, ficando para trás. É sabido também que ao estabelecer um currículo de transição para o retorno presencial das aulas há grandes possibilidades de fortalecimento do vínculo estudantil com o processo do conhecimento, da aprendizagem e da educação em si.

Quanto a análise dos dados, nos oportunizou a compreensão e o reconhecimento das dificuldades existentes neste formato remoto de ensino, evidenciados pelos interlocutores desta pesquisa, sejam eles: professores, mães e alunos. Também tivemos a possibilidade de visualizar o esforço hercúleo dos docentes em se transformar em "super heróis/youtubers" da noite para o dia, muitos deles sem nenhum conhecimento prévio da era digital. As mães e estudantes, com todas as incertezas e críticas, acreditaram nas possibilidades de aprendizagens ofertadas pelas instituições por meio da tecnologia midiática. Não por isso que vamos fugir às críticas, porque elas devem ser feitas para melhorar o ensino e posterior aproveitamento destas ferramentas de trabalho, pois por meio delas também é possível promover Educação.

Diante do quadro esboçado, acreditamos na possibilidade de um currículo que estabeleça o diálogo e o debate como estratégia metodológica, no intuito de favorecer o pensamento crítico e a formação humana em todas as suas nuances sociais, culturais e econômicas. Embora presumamos que, em partes, isso não tenha acorrido, devido às circunstâncias pandêmicas que afetaram não somente os que adquiriram a doença, mas o emocional de todos, pois se não fomos acometidos pelo vírus, conhecemos alguém que foi. Sobretudo neste sentido que apostamos em um "currículo de transição", humanamente pensado para fortalecer o vínculo do estudante com a escola, e consequentemente resgatar, aos poucos, o ideário de uma educação pública inclusiva e de qualidade.

\section{REFERÊNCIAS}

ALMEIDA, L. C.; BETINI, G. A. A qualidade da escola: debatendo princípios rumo à construção de uma qualidade socialmente referenciada. Revista Iberoamericana de Evaluación Educativa, v. 9, n. 2, p. 49-63, 2016. DOI: dx.doi.org/10.15366/riee2016.9.2.003

BACICH, L.; NETO, A. T.; TREVISANI, F. M. Ensino híbrido: personalização e tecnologia na educação. Porto Alegre, RS: Penso, 2015.

BEZERRA, M. A. Da redação ao gênero textual: a didatização da escrita na sala de aula. In: MOURA, D. (Org.). Os desafios da língua: pesquisas em língua falada e escrita. Maceió, AL: EDUFAL, 2008. p. 135-138 
BRASIL. Decreto 9.057, de 25 de maio de 2017. Regulamenta o art. 80 da Lei n ${ }^{\circ}$ 9.394, de 20 de dezembro de 1996 , que estabelece as diretrizes e bases da educação nacional. Brasília, DF, 30 maio 2017. Disponível em: http://www.planalto.gov.br/ccivil_03/_ato20152018/2017/decreto/d9057.htm. Acesso em: 10 fev. 2021.

BRASIL. Organização Pan-Americana de Saúde/Organização Mundial de Saúde. Disponível em: https://www.paho.org/bra. Acesso em: 23 maio 2021.

BRASIL. Ministério da Educação. Parecer CNE/CP n. 5/2020, aprovado em 28 de abril de 2020. Reorganização do Calendário Escolar e da possibilidade de cômputo de atividades não presenciais para fins de cumprimento da carga horária mínima anual, em razão da Pandemia da COVID-19. Brasília, DF, 04 maio 2020. Disponível em:

http://portal.mec.gov.br/index.php?option=com_docman\&view $=$ download\&alias=145011pcp005-20\&category_slug=marco-2020-pdf\&Itemid=30192. Acesso em: 23 maio 2021.

CETIC. Centro Regional de Estudos para o Desenvolvimento da Sociedade da Informação. Pesquisa TIC Domicílios 2018. 2018. Disponível em: https://www.cetic.br/tics/domicilios/2018/domicilios/A4/. Acesso em: 30 jun. 2020.

CIEB. Centro de Inovação para a Educação Brasileira. Planejamento das Secretarias de Educação do Brasil para Ensino Remoto. 2020.

CUNHA, M. I. Ação Educativa. In: MOROSINI, M. C. (Ed.). Enciclopédia de Pedagogia Universitária. Glossário. Brasília, DF: Instituto Nacional de Estudos e Pesquisas educacionais Anísio Teixeira, 2006. v. 2.

FREITAS, L. C. A reforma empresarial da educação: nova direita, velhas ideias. 1. ed. São Paulo, SP: Expressão Popular, 2018.

GÓMEZ, A. I. P. Ensino para a compreensão. In: SACRISTÁN, J. G.; GÓMEZ, A. I. P. Compreender e transformar o ensino. 4. ed. Porto Alegre, RS: Artmed, 1998. p. 67-98.

LIBÂNEO, J. C. Pedagogia e pedagogos, para quê? 12. ed. São Paulo, SP: Cortez, 2010.

LIBÂNEO, J. C. O dualismo perverso da escola pública brasileira: escola do conhecimento para os ricos, escola do acolhimento social para os pobres. Educ. Pesqui., São Paulo (SP), v. 38, n. 1, p. 13-28, 2012. DOI: doi.org/10.1590/S1517-97022011005000001

LIBÂNEO, J. C. Didática. 2. ed. São Paulo, SP: Cortez, 2013.

LIMA, E. S.; SILVA, F. T. O encontro entre o currículo e a avaliação na coordenação pedagógica da escola. Brasília, DF: Editora Kiron, 2020.

MENDES, C. B.; LHAMAS, A. P. B.; MAIA, J. S. S. Aspectos da educação ambiental crítica: reflexões sobre as desigualdades na pandemia da Covid-19. Revista Brasileira De Educação Ambiental (RevBEA), São Paulo (SP), v. 15, n. 4, p. 361-379, 2020. DOI: doi.org/10.34024/revbea.2020.v15.10854 
SACRISTÁN, J. Gimeno. O currículo: uma reflexão sobre a prática. 3. ed. Porto Alegre: ArtMed, 2000.

SANTOMÉ, J. T. Políticas educativas e curriculares na construção de um senso comum neoliberal. Corunha, Espanha: Universidade da Coruña, 2016.

SAVIANI, D. Educação: do senso comum à consciência filosófica. 11. ed. Campinas, SP: Autores Associados, 1996. (Coleção educação contemporânea)

SAVIANI, D. O Plano de Desenvolvimento da Educação: análise do projeto do MEC. Educ. Soc., Campinas (SP), v. 28, n. 100, p. 1231-1255, out. 2007. DOI: doi.org/10.1590/S010173302007000300027

SAVIANI, D. Escola e democracia. Campinas, SP: Autores associados, 2008.

SAVIANI, D. Pedagogia histórico-crítica: primeiras aproximações. 11. ed. rev. Campinas, SP: Autores Associados, 2013.

SAVIANI, D. As implicações da pandemia para a educação, segundo Dermeval Saviani. Vermelho, 30 jul. 2020. Disponível em: https://vermelho.org.br/2020/07/30/as-implicacoesda-pandemia-para-aeducacao-segundo-dermeval-saviani/. Acesso em: 04 fev. 2021.

SILVA, F. T.; BORGES, L. F. F.. Currículo, Narrativa e Diversidade: prescrições ressignificadas. In: Francisco Thiago Silva; Liliane Campos Machado. (Org.). Currículo, Narrativas e Diversidade. 1 ed. Curitiba: Appris, 2019.

SILVA, F. T. S. Currículo de transição: uma saída para a educação pós-pandemia. Revista Educamazônia - Educação Sociedade e Meio Ambiente, Humaitá (AM), ano 13, v. XXV, n. 1, jan./jun. 2020. Disponível em:

https://periodicos.ufam.edu.br/index.php/educamazonia/article/view/7666. Acesso em: 22 fev. 2021.

\section{Como referenciar este artigo}


SILVA, F. T.; SILVA, A. P. Educação, currículo e teoria crítica em tempos de pandemia: o que pensam docentes e a comunidade escolar. Revista Ibero-Americana de Estudos em Educação, Araraquara, v. 16, n. esp. 3, p. 1604-1628, jun. 2021. e-ISSN: 1982-5587. DOI: https://doi.org/10.21723/riaee.v16iesp.3.15300

Submissão em: 05/02/2021

Revisões requeridas em: 30/03/2021

Aprovado em: $12 / 05 / 2021$

Publicado em: 01/06/2021 